Published in final edited form as:

Clin Cancer Res. 2014 September 15; 20(18): 4747-4757. doi:10.1158/1078-0432.CCR-14-0114.

\title{
Phase I Dose-Escalation Study of MEDI-573, a Bispecific, Antiligand Monoclonal Antibody against IGFI and IGFII, in Patients with Advanced Solid Tumors
}

\author{
Paul Haluska ${ }^{1}$, Michael Menefee ${ }^{2}$, Elizabeth R. Plimack ${ }^{3}$, Jonathan Rosenberg ${ }^{4}$, Donald \\ Northfelt ${ }^{5}$, Theresa LaVallee ${ }^{6}$, Li Shi ${ }^{6}$, Xiang-Qing Yu ${ }^{6}$, Patricia Burke ${ }^{6}$, Jaiqi Huang ${ }^{6}$, Jaye \\ Viner $^{6}$, Jennifer McDevitt ${ }^{6}$, and Patricia LoRusso ${ }^{7}$ \\ ${ }^{1}$ Mayo Clinic, Rochester, Minnesota. ${ }^{2}$ Mayo Clinic, Jacksonville, Florida. ${ }^{3}$ Fox Chase Cancer \\ Center, Temple Health, Philadelphia, Pennsylvania. ${ }^{4}$ Dana-Farber Cancer Institute, Boston, \\ Massachusetts. ${ }^{5}$ Mayo Clinic, Scottsdale, Arizona. ${ }^{6}$ Medlmmune, Gaithersburg, Maryland. \\ ${ }^{7}$ Barbara Ann Karmanos Cancer Institute, Detroit, Missouri.
}

\begin{abstract}
Purpose-This phase I, multicenter, open-label, single-arm, dose-escalation, and dose-expansion study evaluated the safety, tolerability, and antitumor activity of MEDI-573 in adults with advanced solid tumors refractory to standard therapy or for which no standard therapy exists.

Experimental Design-Patients received MEDI-573 in 1 of 5 cohorts $(0.5,1.5,5,10$, or 15 $\mathrm{mg} / \mathrm{kg}$ ) dosed weekly or 1 of 2 cohorts ( 30 or $45 \mathrm{mg} / \mathrm{kg}$ ) dosed every 3 weeks. Primary end points included the MEDI-573 safety profile, maximum tolerated dose (MTD), and optimal biologic dose
\end{abstract}

(C) 2014 American Association for Cancer Research.

Corresponding Author: Paul Haluska, Mayo Clinic, 200 First Street, South West, Rochester, MN 55905. Phone: 507-284-3731; Fax: 507-284-1803; haluska.paul@mayo.edu.

Current address for J. Rosenberg: Memorial Sloan-Kettering Cancer Center, New York City, New York; current address for T.

LaVallee, Kolltan Pharmaceuticals, Inc., New Haven, Connecticut; and current address for J. Viner, Curis, Inc., Lexington,

Massachusetts.

Supplementary data for this article are available at Clinical Cancer Research Online (http://clincancerres.aacrjournals.org/).

Prior presentation: Presented in part at the 22nd EORTC-NCI-AACR symposium on Molecular Targets and Cancer Therapeutics, Berlin, Germany, November 16-19, 2010, and at the American Society of Clinical Oncology BreastCancer Symposium,San Francisco, California,September 8-10, 2011.

Authors' Contributions

Conception and design: P. Haluska, T. LaVallee, L. Shi, X.-Q. Yu, J. Huang, J. Viner, J. McDevitt, P. LoRusso

Development of methodology: T. LaVallee, L. Shi, J. Huang, J. McDevitt, P. LoRusso

Acquisition of data (provided animals, acquired and managed patients, provided facilities, etc.): P. Haluska, M. Menefee, E.R

Plimack, J. Rosenberg, D. Northfelt, T. LaVallee, P. Burke, J. McDevitt

Analysis and interpretation of data (e.g., statistical analysis, biostatistics, computational analysis): J. Rosenberg, D. Northfelt, T.

LaVallee, L. Shi, X.-Q. Yu, P. Burke, J. Huang, J. McDevitt

Writing, review, and/or revision of the manuscript: P. Haluska, M. Menefee, E.R. Plimack, J. Rosenberg, D. Northfelt, T. LaVallee, L. Shi, X.-Q. Yu, P. Burke, J. Huang, J. Viner, J. McDevitt, P. LoRusso

Administrative, technical, or material support (i.e., reporting or organizing data, constructing databases): J. McDevitt

Study supervision: P. Haluska, J. Rosenberg, D. Northfelt, J. McDevitt

Disclosure of Potential Conflicts of Interest

T. LaVallee has ownership interest (including patents) in AstraZeneca. X.-Q. Yu and J. McDevitt are employees of MedImmune LLC.

J. Huang is an employee of AstraZeneca. No potential conflicts of interest were disclosed by the other authors. 
(OBD). Secondary end points included MEDI-573 pharmacokinetics (PK), pharmacodynamics, immunogenicity, and antitumor activity.

Results-In total, 43 patients (20 with urothelial cancer) received MEDI-573. No dose-limiting toxicities were identified, and only 1 patient experienced hyperglycemia related to treatment. Elevations in levels of insulin and/or growth hormone were not observed. Adverse events observed in $>10 \%$ of patients included fatigue, anorexia, nausea, diarrhea, and anemia. PK evaluation demonstrated that levels of MEDI-573 increased with dose at all dose levels tested. At doses $>5 \mathrm{mg} / \mathrm{kg}$, circulating levels of insulin-like growth factor (IGF)-I and IGFII were fully suppressed. Of 39 patients evaluable for response, none experienced partial or complete response and 13 had stable disease as best response.

Conclusions-The MTD of MEDI-573 was not reached. The OBD was $5 \mathrm{mg} / \mathrm{kg}$ weekly or 30 or $45 \mathrm{mg} / \mathrm{kg}$ every 3 weeks. MEDI-573 showed preliminary antitumor activity in a heavily pretreated population and had a favorable tolerability profile, with no notable perturbations in metabolic homeostasis.

\section{Introduction}

The insulin-like growth factor (IGF) signaling system is an ubiquitous, complex, tightly regulated pathway that has potent effects on cell proliferation, survival, differentiation, and transformation (1). Two circulating ligands, IGFI and IGFII (1), are tightly regulated by at least 6 circulating IGF-binding proteins (IGFBP; ref. 2). Both IGFI and IGFII transduce signaling through the type 1 IGF receptor (IGF1R), a transmembrane receptor tyrosine kinase $(1,3)$. The insulin receptor isoform A (IR-A) is also an IGF signaling receptor through the binding of IGFII (4). Conversely, the insulin receptor isoform B (IR-B) is a purely metabolic isoform capable of binding only insulin at physiologic concentrations (4). Further mitogenic regulation of IGFII occurs via a nonsignaling membrane receptor, IGFIIR (5). Adding to the complexity of the system, insulin receptors and IGF1R can form hybrid receptors that have varying affinities for IGF ligands as well as insulin (6).

Increased expression of IGF1R, IGFI, and IGFII has been demonstrated in a number of cancers, including breast, colorectal, thyroid, bladder, hepatocellular carcinoma, and osteosarcoma (7-11). In urothelial cancer cells, increased expression of IGF1R has been associated with promoting motility and invasion of cancer cells (8), suggesting the potential therapeutic value of an agent that targets the IGF signaling pathway in this population. There is compelling evidence in multiple tumor types, models, and clinical samples that dysregulation of IGF signaling has a substantial impact on cancer growth, survival, and resistance to clinically useful cancer therapies. For example, IGF signaling has been implicated in resistance to hormonal therapy in breast cancer $(12,13)$. Blockade of IGF signaling may enhance the effects of hormonal therapy $(14,15)$. Similarly, dysregulated IGF signaling has been implicated as a mechanism of resistance to therapies targeted against receptor tyrosine kinases (16), including trastuzumab (17). Multiple studies have also demonstrated that IGF signaling inhibition can enhance the effects of cytotoxic chemotherapy $(18,19)$, potentially expanding the scope of clinical benefit achieved with therapies that target IGF.

Clin Cancer Res. Author manuscript; available in PMC 2015 March 29. 
In clinical studies, monoclonal antibodies directed against IGF1R have been the focus of most strategies targeting IGF (20-24). However, emerging data suggest that IGF signaling through IR-A, which is not blocked by IGF1R-targeted monoclonal antibodies, may be as important as IGF1R-mediated IGF signaling. For example, the IR-A receptor has been shown to be the predominant IGF signaling receptor in breast cancer $(25,26)$, suggesting that the blockade of IGF signaling through IGF1R inhibition may be an inadequate treatment strategy. Expression of IR-A also is common in ovarian carcinoma (27), osteosarcoma (28), acute myelogenous leukemia (29), and other malignancies (30-32), suggesting that IGF blockade through both IGF1R and IR-A may be warranted (21).

MEDI-573 is a dual-targeting human monoclonal antibody that neutralizes the IGFI and IGFII ligands, resulting in inhibition of IGF signaling through both IGF1R and IR-A in a number of cancer cell lines; importantly, metabolic insulin action through IR-B is not altered using this approach (33). Thus, we hypothesized that the antiligand approach of MEDI-573 may improve on the incomplete IGF signaling blockade that occurs with IGF1R-directed monoclonal antibodies. Here we report the results of the first clinical study of MEDI-573 in adults with advanced solid tumors refractory to standard therapy or for which no standard therapy exists.

\section{Materials and Methods}

\section{Patient population}

Men and women ages 18 years or older with histologically confirmed advanced solid tumors for which no curative or standard therapies were available were eligible for inclusion. Patients were required to have a Karnofsky performance status $\lcm{60}$, life expectancy of at least 12 weeks, and adequate hematologic (hemoglobin $\geq 10 \mathrm{~g} / \mathrm{dL}$, absolute neutrophil count $\geq 1,500 / \mathrm{mm}^{3}$, platelet count $\geq 100,000 / \mathrm{mm}^{3}$ ) and organ function [serum aspartate aminotransfer ase and alanine aminotransferase levels $\leq 2$ times institutional upper limit of normal (ULN), serum bilirubin levels $\leq 1.5$ times ULN, and creatinine clearance $\geq 60 \mathrm{~mL} /$ min]. Prior radiation therapy was allowed, provided that exposure did not exceed $25 \%$ of total marrow space, and toxicities from any previous cancer therapies must have recovered to grade $<2$ before enrollment. Patients were excluded if they received any concurrent therapy for cancer, chemotherapy, or small molecule-targeted therapy within 4 weeks of first MEDI-573 dose, immunotherapy or biologic therapies within 6 weeks of study treatment, or previous therapy with monoclonal antibodies directed against IGF1R. Additional exclusion criteria included: poorly controlled diabetes mellitus; New York Heart Association grade $\geq 2$ congestive heart failure; history of myocardial infarction, unstable angina, transient ischemic attack, or stroke within 6 months of treatment with study medication; history of other invasive malignancy within 5 years (except for cervical carcinoma in situ, nonmelanomatous carcinoma of the skin or ductal carcinoma in situ of the breast that has been surgically cured) or documented brain metastasis; evidence of significant active infection; use of immunosuppressive medications or systemic steroids within 7 days of first dose of MEDI-573; pregnancy or lactation; clinically significant electrocardiogram (ECG) abnormality; or evidence of any condition that may have compromised patient safety during the study. 


\section{Objectives}

The primary objectives were to determine the maximum tolerated dose (MTD) and optimal biologic dose (OBD) of MEDI-573 in patients with solid tumors. The end points included dose-limiting toxicity, adverse events (AE), and serious AEs (SAE). Secondary objectives included determination of the pharmacokinetic (PK) and immunogenic properties of MEDI-573, pharmacodynamic (PD) effects of MEDI-573 on circulating plasma levels of IGFI and IGFII, and the antitumor activity in response to MEDI-573 administration in patients with solid tumors. Exploratory analyses were conducted to evaluate the relationship of IGF pathway-related components at the mRNA and miRNA level in tumor biopsies obtained pre- and post-MEDI-573 treatment, and to identify and characterize associations between baseline circulating tumor cells (CTC) and clinical response.

\section{Study design and dose-escalation cohorts}

This phase I, multicenter, open-label, single-arm, dose-escalation, and dose-expansion study was conducted at 6 sites in the United States from March 2009 to July 2011

(ClinicalTrials.gov registry number: NCT00816361). The study protocol was approved by the ethics committee at each participating center, and all patients provided written informed consent before study participation.

Patients were assigned to sequential cohorts of 3 to 6 evaluable patients each receiving 1 of 5 doses of MEDI-573 $(0.5,1.5,5,10$, or $15 \mathrm{mg} / \mathrm{kg}$ ) every 7 days in 21-day cycles (escalation cohorts 1-5). If the first 3 patients in the $1.5 \mathrm{mg} / \mathrm{kg}$ cohort did not experience a dose-limiting toxicity (DLT) after 21 days of treatment, then enrollment in the $5 \mathrm{mg} / \mathrm{kg}$ cohort would begin. Higher-dose cohorts were enrolled following the same process. If 2 or more subjects within a cohort experienced a DLT within the first 21 days of treatment, then the MTD was exceeded and no further subjects were enrolled in that cohort. If 0 of 3 or fewer than 1 of 6 patients in cohort 5 experienced a DLT within the first 21 days of treatment, subsequent patients were enrolled in cohorts receiving 30 or $45 \mathrm{mg} / \mathrm{kg}$ of MEDI-573 every 3 weeks (escalation cohorts 6 and 7). Enrollment in the $45 \mathrm{mg} / \mathrm{kg}$ cohort was dependent on PK, PD, immunogenicity, and safety assessments of MEDI-573 at the $30 \mathrm{mg} / \mathrm{kg}$ dose level. Intrapatient dose escalation was not allowed. MEDI-573 was administered as a 60-minute intravenous infusion once every 7 days at doses $\leq 5 \mathrm{mg} / \mathrm{kg}$; or one 90 -minute intravenous infusion for the 30 and $45 \mathrm{mg} / \mathrm{kg}$ doses. For cohorts 1 to 5 , after the first cycle, a dose could be delayed up to 7 days based on hematologic and nonhematologic toxi-cities; however, administration of all doses was required for the cycle to be considered complete. Dose delays were not allowed in the 30 and $45 \mathrm{mg} / \mathrm{kg}$ cohorts. Patients who did not receive all required doses within a cycle did not advance to the next cycle and were removed from the study. Treatment with MEDI-573 continued until unacceptable toxicity, disease progression, or other reasons for withdrawal were observed.

\section{Dose-expansion cohorts}

The dose-expansion phase was designed to evaluate the PK and PD parameters and to determine tumor response in 2 cohorts of approximately 10 patients each with advanced urothelial cancer (e.g., bladder cancer) at dose levels of $5 \mathrm{or} 15 \mathrm{mg} / \mathrm{kg}$ every 7 days. The first 10 patients enrolled into the dose-expansion phase were treated with MEDI-573 15 
$\mathrm{mg} / \mathrm{kg}$. The decision to continue enrollment in the lower $5-\mathrm{mg} / \mathrm{kg}$ dose-expansion cohort was based on PD assessments. The dosing schedule was the same as for the dose-escalation cohorts.

\section{Safety assessments}

Patient safety and tolerability were assessed through physical examinations, vital signs, ECGs, routine laboratory evaluations, and assessment of treatment-related AE and SAEs and graded using the Common Terminology Criteria for Adverse Events (CTCAE) version 4.0. All AEs occurring within 30 days after the last dose of MEDI-573 were reported by the investigator. Serious AEs included any AE that resulted in death, was immediately lifethreatening (i.e., an event wherein the patient was at risk of dying at the time of the event), required inpatient hospitalization or prolongation of hospitalization, resulted in persistent or substantial disability/incapacity, resulted in a congenital anomaly in the offspring of a patient, or may have jeopardized the patient or required medical intervention to prevent one of the previously mentioned outcomes. Complete physical examinations were performed at screening, after every 2 cycles, and at the end of treatment. A physical examination for the purpose of disease evaluation was completed at screening and on the first day of each cycle. ECGs were performed at screening, on day 1 of the first treatment cycle before and at completion of infusion, and 6 hours after completion (in the MEDI-573 0.5, 1.5, 5.0, 10.0, and $15.0 \mathrm{mg} / \mathrm{kg}$ and dose-expansion cohorts only), on day 1 of all subsequent cycles before dosing, at end of treatment, and 30 days following the last dose of MEDI-573. Vital signs were assessed immediately before MEDI-573 infusion, every 15 minutes during the infusion, at the end of the infusion ( \pm 5 minutes), and 30 and 60 minutes ( \pm 5 minutes) postinfusion. Routine laboratory evaluations, including serum chemistry and hematological assessments of complete blood count with differential and platelet count occurred at screening, on days $1,3,8$, and 15 of the first treatment cycle, on days 1,8 , and 15 of subsequent cycles, and at end of treatment. In the dose-escalation cohorts, these were assessed on days 1, 3, and 8 of the first treatment cycle, and on days 1 and 8 of subsequent cycles. Hemoglobin A1c levels were evaluated at screening and at the end of treatment. Urine samples were assessed at screening, on each treatment day of every cycle, and at the end of treatment; in the dose-escalation cohort, urinalysis occurred at screening, on the first day of each treatment cycle, and at the end of treatment.

\section{PK and immunologic evaluations}

Blood samples were collected immediately before and following MEDI-573 infusions (all cycles), as well as 2 and 6 hours postinfusion $(0.5,1.5,5.0,10.0$, and $15.0 \mathrm{mg} / \mathrm{kg}$ and doseexpansion cohorts only) on day 1 of cycle 1 . Additional samples were collected 24 and 48 hours ( \pm 2 hours) following the first infusion of cycle 1 , and pre- and post-infusion $( \pm 5$ minutes) for each subsequent treatment. Samples for evaluation of anti-MEDI-573 antibodies were collected at screening and before each infusion. Free MEDI-573 in serum was quantitated using a validated electrochemiluminescence assay in which unlabeled and ruthenium-labeled mouse anti-idiotype monoclonal antibodies were used as the capture and detection reagents, respectively. The PK parameters, including $C_{\max }, T_{\max }$, and AUC, were determined using PK data after the first dose only using a noncompartmental approach with WinNonlin Professional version 5.2 (Pharsight Corp.). Plasma concentrations of free IGFI 
and IGFII were measured using an electrochemiluminescence assay in which biotinylated MEDI-573 was used as the capture reagent and a ruthenium-labeled polyclonal antibody was used as the detection reagent. The OBD was defined as the dose at which all circulating free IGFI and IGFII ligands was sequestered by MEDI-573.

\section{Antitumor activity}

Disease evaluations were performed by computed tomography (CT) or magnetic resonance imaging (MRI) at screening, every 2 cycles, at end of treatment or until progressive disease during treatment, and at the discretion of the investigator. For patients who discontinued treatment for reasons other than progressive disease or initiation of alternative treatment, disease evaluations were performed every 3 months until progressive disease. Tumor measurements and assessments were based on Response Evaluation Criteria in Solid Tumors (RECIST; ref. 34). Antitumor activity was assessed based on objective response rate (ORR), time to response (TTR), duration of response (DR), time to progression (TTP), progressionfree survival (PFS), and overall survival (OS).

\section{Survival and posttherapy follow-up}

Every 3 months ( \pm 2 weeks) after the last dose of MEDI-573, survival status was assessed and complete physical examinations and disease evaluations were performed until the end of study or patient death. Presence of anti-MEDI-573 antibodies, serum concentrations of MEDI-573, and levels of blood biomarkers were assessed 3 months following the last dose of MEDI-573.

\section{Correlative studies}

To understand the effects of MEDI-573 on IGF1R pathways as well as proliferation and invasion in human cancer, we studied the mRNA expression profiles in biopsy samples from patients with bladder cancer before and after treatment with MEDI-573 (see Supplementary Methods).

\section{CTC analysis}

CTC analysis was performed on samples from patients in the MEDI-573 30 and $45 \mathrm{mg} / \mathrm{kg}$ dose-escalation cohorts and in the expansion cohorts with available baseline CTC values $(n$ $=24$, including 18 patients with bladder cancer and 6 patients with other solid tumors from the MEDI-573 30 and $45 \mathrm{mg} / \mathrm{kg}$ escalation cohorts). Methods were described previously (35), but this analysis used the CellSearch CXC Kit (Janssen Diagnostics). For evaluating CTCs as a prognostic marker for survival, patients were grouped by baseline CTC values of either less than 5 or 5 or more, as these cutoffs have been established as prognostic for breast cancer (36) and prostate cancer (37). The cutoff of 5 CTCs was used in this case, although the majority of CTC data were from patients with bladder cancer, because no cutoff point has been established for CTCs in bladder cancer. However, it should be noted that using a cutoff of 3 CTCs, which has been used for colorectal cancer $(38,39)$, yielded similar findings with this dataset.

Clin Cancer Res. Author manuscript; available in PMC 2015 March 29. 


\section{Statistical analysis}

For the dose-escalation phase, a minimum of 21 evaluable patients ( 3 patients in each dose cohort) were required if no DLTs occurred. The safety population included all patients who received at least 1 dose of MEDI-573. The efficacy evaluable population included all patients who received any MEDI-573 treatment and had at least 1 post-baseline tumor assessment. The MTD evaluable population included patients who completed at least 1 full cycle of MEDI-573 (3 doses in cohorts 1-5 or 1 dose in cohorts 6-7, and followed $\geq 21$ days after the first dose) or discontinued because of DLTs. Nonevaluable patients were replaced in the same cohort. All DLTs were assessed during the first treatment cycle and were defined as any grade 3 or higher toxicity for which a cause other than treatment with MEDI-573 could not be reasonably justified. Exceptions were fasting serum glucose abnormalities of up to grade 3 with duration < 24 hours, grade 3 fever not considered an SAE that resolved to normal or baseline within 24 hours of treatment, or grade 3 rigors or chills that responded to optimal therapy.

All safety end points were summarized descriptively. AEs and SAEs were summarized by cohort, system organ class, severity, and relationship to MEDI-573 treatment for 30 days following the last dose. PK and immunogenic assessments were summarized descriptively. For MTD and OBD assessments, descriptive statistics were used to summarize the occurrence of DLTs by cohort. The TTR, DR, TTP, PFS, and OS were evaluated using Kaplan-Meier methods. For the CTC analysis, time-to-event data were visualized using Kaplan-Meier curves and were evaluated with log-rank (Mantel-Cox) tests.

\section{Results}

Patients

A total of 43 patients, including 23 in the dose-escalation phase and 20 in the doseexpansion phase with urothelial (bladder) cancer, received MEDI-573 (Fig. 1). The patient population was predominantly white $(90.7 \%)$ and male $(58.1 \%)$, with a mean age of 62.6 years and a mean weight of $82.8 \mathrm{~kg}$ (Table 1). The most common tumor type was bladder (39.5\% of patients) because of the dose-expansion cohorts. Approximately $91 \%$ of patients presented with stage IV tumors.

\section{Safety}

The MTD was not reached after enrolling patients through the highest dose level on the weekly ( $15 \mathrm{mg} / \mathrm{kg}$ ) or every 3 week $(45 \mathrm{mg} / \mathrm{kg}$ ) schedules. No DLTs ( zgrade 3 AE during the first cycle) were observed at any dose level. Overall, the most common AEs were decreased appetite (46.5\%), fatigue (41.9\%), nausea (32.6\%), diarrhea (25.6\%), vomiting (23.3\%), and abdominal pain (20.9\%). The most common treatment-related AEs were fatigue (27.9\%), decreased appetite (23.2\%), nausea (18.6\%), diarrhea (16.3\%), and anemia (11.6\%). Most AEs were sgrade 2 (Table 2). Overall, 34 SAEs occurred in 17 patients; 1 patient treated with $15.0 \mathrm{mg} / \mathrm{kg}$ experienced 2 treatment-related SAEs (Table 3). Five of 43 patients (11.6\%) in the dose-escalation phase and 1 of 20 patients $(5.0 \%)$ in the doseexpansion phase discontinued treatment because of AEs. Three deaths occurred during the study, all because of progressive disease and none considered related to MEDI-573

Clin Cancer Res. Author manuscript; available in PMC 2015 March 29. 
treatment. Clinically, significant changes in serum glucose related to study treatment were rare, observed in 1 of 43 patients. No clinically significant changes to insulin or somatotropin levels, hematologic parameters, or in ECGs were observed. No neutralizing antibodies against MEDI-573 were detected in any patient sample.

\section{PKs and PDs}

The MEDI-573 serum concentration-time profile is presented in Fig. 2A. PK parameters determined by noncompartmental analysis are summarized in Table 4. Serum concentrations of MEDI-573 increased with dose. The OBD, defined as full suppression of both IGFI (Fig. 2B) and IGFII (Fig. 2C) in the plasma of patients receiving MEDI-573, was achieved at a once weekly dose of $5.0 \mathrm{mg} / \mathrm{kg}$ or higher and at 30.0 or $45 \mathrm{mg} / \mathrm{kg}$ every 3 weeks.

\section{Antitumor activity}

Four patients in the dose-escalation phase were not included in the efficacy evaluable population: 2 because of AEs, 1 because of withdrawal of consent, and 1 who entered hospice care. No partial or complete responses were observed on study. Stable disease occurred in 13 of 39 (33\%) patients in the dose-escalation cohorts and 4 of $20(20 \%)$ patients in the dose-expansion cohorts with urothelial cancer. Stable disease lasting at least 12 weeks was reported in 8 of 39 (21\%) efficacy evaluable patients, 3 of whom were in the dose-expansion cohorts. The median TTP and PFS were 1.4 months in both the overall efficacy evaluable patients and the dose-expansion cohorts. The median OS were 4.8 and 4.0 months in the overall efficacy evaluable population and dose-expansion cohorts, respectively.

\section{Correlative studies}

Eleven pairs of pretreatment and posttreatment mRNA biopsy samples from the doseexpansion cohorts were studied. Six pairs of samples were from the $5-\mathrm{mg} / \mathrm{kg}$ cohort and 5 pairs were from the $15-\mathrm{mg} / \mathrm{kg}$ cohort. A trend toward inhibition was observed with MEDI-573 on cancer proliferation genes (AURKA, CCNB1, MKI67, and MYBL2), cancer invasion genes (CTSL2 and MMP11), and the bladder cancer marker UPK3A, but these changes were not statistically significant (see Supplementary Fig. S1). The mRNA differential expression of IGF pathway genes, including IGF1,IGF2,IGFIR, and IR-A, were also studied, and no statistically significant differences were observed by comparing pretreatment and posttreatment samples in the 2 cohorts. A trend of dose-dependent decreases in mRNA expression of Grb2, AKT1, and mTOR was observed by comparing the 5 and $15 \mathrm{mg} / \mathrm{kg}$ cohorts, but these differences were not statistically significant owing to small sample sizes. The relationship between the mRNA differential expression and PFS also were investigated (data not shown). However, the results were not conclusive because of the limited sample size.

\section{CTC analysis}

Pretreatment CTC levels, ranging from 0 to 505 CTCs, were measured in patients participating in the dose-expansion cohorts and in the every 3 weeks dose-level groups (30 and $45 \mathrm{mg} / \mathrm{kg}$ ). Six patients had 0 CTCs, 9 patients had 1 to 4 CTCs, and 3 patients had 5 or 
more CTCs in the dose-expansion cohorts. Of the 24 subjects with baseline CTC values, 8 , 12, and 4 patients had 0 CTCs, 1 to 4 CTCs, and 5 or more CTCs, respectively. Overall survival was correlated with the number of pretreatment CTCs ( $25 / 7.5$ or $<5 / 7.5 \mathrm{~mL}$ ). For all patients with baseline CTC samples $(n=24)$, patients with at least $5 \mathrm{CTC} / 7.5 \mathrm{~mL}(n=4)$ had inferior survival duration compared with patients with $<5 \mathrm{CTC} / 7.5 \mathrm{~mL}$ ( $n=20 ; 2.5$ vs. 4.8 months, respectively; $P=0.006$ ). When analyzed separately, patients in the expansion (urothelial cancer) cohorts $(n=18)$ with $25 \mathrm{CTC} / 7.5 \mathrm{~mL}(n=3)$ had inferior survival duration compared with patients with $<5 \mathrm{CTC} / 7.5 \mathrm{~mL}$ ( $n=15 ; 3.2$ months vs. 4.8 months, respectively; $P=0.052$ ). These results should be interpreted with caution, given the small number of patients included in the analysis.

\section{Discussion}

Effectively targeting the IGF system for the purposes of anticancer therapy has proven challenging. Numerous therapies have been developed targeting the pathway, which for the most part have been tolerable both as single agents and in combination with other agents. However, it is conceivable that the untoward metabolic consequence of IGF-targeting agents may not only lead to undesirable AEs, but also may be counterproductive to antitumor activity.

For example, hyperglycemia has been demonstrated to be a class effect AE in response to anti-IGF1R monoclonal antibodies; however, some agents are more likely to stimulate elevated glucose levels than others $(20-22,24)$. Although not fully understood, the proposed mechanism of glucose-level elevation is disruption of the negative feedback loop at the hypothalamic level by anti-IGF1R monoclonal antibodies, leading to increased growth hormone secretion and resultant hyperinsulinemia, insulin resistance, and, ultimately, hyperglycemia (40). Importantly, this mechanism is insulin receptor independent, as antiIGF1R therapies do not bind to the insulin receptor, even at supraphysiologic levels (41-43). No occurrence of hyper-insulinemia or elevations in growth hormone was noted in patients receiving MEDI-573, and hyperglycemia was rare (1 case). These data suggest that an antiligand approach to targeting the IGF system may have less impact on metabolic homeostasis. However, further studies comparing such agents in a clinical study are necessary to confirm this finding. The observed lack of hyperglycemia in response to MEDI-573 also suggests that the negative feedback disruption mechanism described above, which should be disrupted by antiligand and anti-IGF1R monoclonal antibodies alike, is not a sufficient explanation. It should be noted that this difference may be because of differences in target interactions or in levels of blockade by the 2 different methods; however, these mechanisms require further study.

Insulin receptor activation by insulin may also explain the suboptimal therapeutic benefit of monoclonal antibodies targeting IGF1R. High insulin secretion and insulin receptor expression are associated with poor cancer outcomes and may attenuate the benefits of IGF1R targeting (44-48). Thus, the unopposed hyperinsulinemia stimulated by anti-IGF1Rdirected monoclonal antibodies may be counterproductive to the antitumor effects of blocking IGF signaling through IGF1R (49). MEDI-573 has no interactions with insulin or insulin receptors (33). Thus, the antiligand approach may have an advantage over anti- 
IGF1R monoclonal antibodies in this regard. Of note, there was no clear modulation of insulin receptor isoforms or other IGF signaling-related proteins evaluated in response to MEDI-573. However, these results are limited by the number of patients evaluated.

Although there was a correlation between patient outcomes and pretreatment CTC enumeration, it is likely that this is reflective of patients with poor prognoses as opposed to lack of benefit from MEDI-573, as previously described $(50,51)$.

MEDI-573 was clearly effective at clearing plasma IGFI and IGFII at doses greater than 5 $\mathrm{mg} / \mathrm{kg}$ weekly. Suppression of IGF ligands at the tumor site, wherein the additional impact of acidic or hypoxic conditions exist, remains to be investigated (52-54). As no maximally tolerated dose was reached and AEs did not increase with increasing exposure of MEDI-573, we recommend the maximum administered dose for phase II investigations, which was $15 \mathrm{mg} / \mathrm{kg}$ on a weekly basis or $45 \mathrm{mg} / \mathrm{kg}$ every 3 weeks. This is supported by preclinical data indicating that complete IGF signaling blockade, but not IGF1R targeting alone, enhances the antitumor effects of hormonal therapy $(14,55)$. In mRNA expression studies in hormone receptor-positive and human epidermal growth factor receptor 2 (HER2)-negative tumor tissues, a positive correlation was found between mRNA ratios of IR-A and IR-B and the expression of multiple proliferation genes, and a more prominent IRA:IR-B expression differential in luminal-B breast cancers (26). The association of increased IR-A:IR-B ratio with the luminal-B subtype suggests that these patients could potentially respond to therapy that targets both IGF1R and IR-A. In conclusion, this study suggests preliminary antitumor activity in the context of a heavily pretreated population and an acceptable safety profile with MEDI-573, thus warranting further clinical investigation. An ongoing phase I/II study (NCT01446159) is evaluating MEDI-573 in combination with hormonal therapy (an aromatase inhibitor) in patients with hormone receptor-positive, HER2-negative, metastatic breast cancer.

\section{Supplementary Material}

Refer to Web version on PubMed Central for supplementary material.

\section{Acknowledgments}

The authors thank Diana Swanson, (MedImmune), and Amy Zannikos, PharmD, of Peloton Advantage, LLC for medical writing and editorial support, which were funded by MedImmune.

Grant Support

This study was sponsored by MedImmune. Medical writing and editorial support were provided by Kristen W. Quinn, PhD, and Amy Zannikos, PharmD, of Peloton Advantage and were funded by MedImmune. No author received an honorarium or other form of financial support related to the development of this article.

The costs of publication of this article were defrayed in part by the payment of page charges. This article must therefore be hereby marked advertisement in accordance with 18 U.S.C. Section 1734 solely to indicate this fact.

\section{References}

1. Pollak M. The insulin and insulin-like growth factor receptor family in neoplasia: an update. Nat Rev Cancer. 2012; 12:159-69. [PubMed: 22337149] 
2. Perks CM, Holly JM. IGF binding proteins (IGFBPs) and regulation of breast cancer biology. J Mammary Gland Biol Neoplasia. 2008; 13:455-69. [PubMed: 19031049]

3. Baserga R, Peruzzi F, Reiss K. The IGF-1 receptor in cancer biology. Int J Cancer. 2003; 107:8737. [PubMed: 14601044]

4. Frasca F, Pandini G, Scalia P, Sciacca L, Mineo R, Costantino A, et al. Insulin receptor isoform A, a newly recognized, high-affinity insulin-like growth factor II receptor in fetal and cancer cells. Mol Cell Biol. 1999; 19:3278-88. [PubMed: 10207053]

5. Schmidt B, Kiecke-Siemsen C, Waheed A, Braulke T, von FK. Localization of the insulin-like growth factor II binding site to amino acids 1508-1566 in repeat 11 of the mannose 6-phosphate/ insulin-like growth factor II receptor. J Biol Chem. 1995; 270:14975-82. [PubMed: 7797478]

6. Soos MA, Whittaker J, Lammers R, Ullrich A, Siddle K. Receptors for insulin and insulin-like growth factor-I can form hybrid dimers. Char-acterisation of hybrid receptors in transfected cells. Biochem J. 1990; 270:383-90. [PubMed: 1698059]

7. Samani AA, Yakar S, LeRoith D, Brodt P. The role of the IGF system in cancer growth and metastasis: overview and recent insights. Endocr Rev. 2007; 28:20-47. [PubMed: 16931767]

8. Metalli D, Lovat F, Tripodi F, Genua M, Xu SQ, Spinelli M, et al. The insulin-like growth factor receptor I promotes motility and invasion of bladder cancer cells through Akt- and mitogenactivated protein kinase-dependent activation of paxillin. Am J Pathol. 2010; 176:2997-3006. [PubMed: 20395438]

9. Zhao H, Grossman HB, Spitz MR, Lerner SP, Zhang K, Wu X. Plasma levels of insulin-like growth factor-1 and binding protein-3, and their association with bladder cancer risk. J Urol. 2003; 169:714-7. [PubMed: 12544349]

10. Gallagher EM, O'Shea DM, Fitzpatrick P, Harrison M, Gilmartin B, Watson JA, et al. Recurrence of urothelial carcinoma of the bladder: a role for insulin-like growth factor-II loss of imprinting and cytoplasmic E-cadherin immunolocalization. Clin Cancer Res. 2008; 14:6829-38. [PubMed: 18980977]

11. Rochester MA, Patel N, Turney BW, Davies DR, Roberts IS, Crew J, et al. The type 1 insulin-like growth factor receptor is over-expressed in bladder cancer. BJU Int. 2007; 100:1396-401. [PubMed: 17645417]

12. Parisot JP, Hu XF, DeLuise M, Zalcberg JR. Altered expression of the IGF-1 receptor in a tamoxifen-resistant human breast cancer cell line. Br J Cancer. 1999; 79:693-700. [PubMed: 10070856]

13. Knowlden JM, Hutcheson IR, Barrow D, Gee JM, Nicholson RI. Insulin-like growth factor-I receptor signaling in tamoxifen-resistant breast cancer: a supporting role to the epidermal growth factor receptor. Endocrinology. 2005; 146:4609-18. [PubMed: 16037379]

14. Hou X, Huang F, Macedo LF, Harrington SC, Reeves KA, Greer A, et al. Dual IGF-1R/InsR inhibitor BMS-754807 synergizes with hormonal agents in treatment of estrogen-dependent breast cancer. Cancer Res. 2011; 71:7597-607. [PubMed: 22042792]

15. Lee AV, Weng CN, Jackson JG, Yee D. Activation of estrogen receptor-mediated gene transcription by IGF-I in human breast cancer cells. J Endocrinol. 1997; 152:39-47. [PubMed: 9014838]

16. Cortot AB, Repellin CE, Shimamura T, Capelletti M, Zejnullahu K, Ercan D, et al. Resistance to irreversible EGF receptor tyrosine kinase inhibitors through a multistep mechanism involving the IGF1R pathway. Cancer Res. 2013; 73:834-43. [PubMed: 23172312]

17. Lu Y, Zi X, Zhao Y, Mascarenhas D, Pollak M. Insulin-like growth factor-I receptor signaling and resistance to trastuzumab (Herceptin). J Natl Cancer Inst. 2001; 93:1852-7. [PubMed: 11752009]

18. Buck E, Eyzaguirre A, Rosenfeld-Franklin M, Thomson S, Mulvihill M, Barr S, et al. Feedback mechanisms promote cooperativity for small molecule inhibitors of epidermal and insulin-like growth factor receptors. Cancer Res. 2008; 68:8322-32. [PubMed: 18922904]

19. Duan Z, Choy E, Harmon D, Yang C, Ryu K, Schwab J, et al. Insulin-like growth factor-I receptor tyrosine kinase inhibitor cyclolignan picropodophyllin inhibits proliferation and induces apoptosis in multidrug resistant osteosarcoma cell lines. Mol Cancer Ther. 2009; 8:2122-30. [PubMed: 19638450] 
20. Atzori F, Tabernero J, Cervantes A, Prudkin L, Andreu J, Rodriguez-Braun E, et al. A phase I pharmacokinetic and pharmacodynamic study of dalotuzumab (MK-0646), an anti-insulin-like growth factor-1 receptor monoclonal antibody, in patients with advanced solid tumors. Clin Cancer Res. 2011; 17:6304-12. [PubMed: 21810918]

21. Haluska P, Hou X, Huang F, Harrington S, Greer A, Macedo L, et al. Complete IGF signaling blockade by the dual-kinase inhibitor, BMS-754807, is sufficient to overcome tamoxifen and letrozole resistance in vitro and in vivo [abstract 402]. Cancer Res. 2009; 69:402.

22. Kurzrock R, Patnaik A, Aisner J, Warren T, Leong S, Benjamin R, et al. A phase I study of weekly R1507, a human monoclonal antibody insulin-like growth factor-I receptor antagonist, in patients with advanced solid tumors. Clin Cancer Res. 2010; 16:2458-65. [PubMed: 20371689]

23. Reidy DL, Vakiani E, Fakih MG, Saif MW, Hecht JR, Goodman-Davis N, et al. Randomized, phase II study of the insulin-like growth factor-1 receptor inhibitor IMC-A12, with or without cetuximab, in patients with cetuximab- or panitumumab-refractory metastatic colorectal cancer. J Clin Oncol. 2010; 28:4240-6. [PubMed: 20713879]

24. Tolcher AW, Sarantopoulos J, Patnaik A, Papadopoulos K, Lin CC, Rodon J, et al. Phase I, pharmacokinetic, and pharmacodynamic study of AMG 479, a fully human monoclonal antibody to insulin-like growth factor receptor 1. J Clin Oncol. 2009; 27:5800-7. [PubMed: 19786654]

25. Harrington SC, Weroha SJ, Reynolds C, Suman VJ, Lingle WL, Haluska P. Quantifying insulin receptor isoform expression in FFPE breast tumors. Growth Horm IGF Res. 2012; 22:108-15. [PubMed: 22551578]

26. Huang J, Morehouse C, Streicher K, Higgs BW, Gao J, Czapiga M, et al. Altered expression of insulin receptor isoforms in breast cancer. PLoS ONE. 2011; 6:e26177. [PubMed: 22046260]

27. Kalli KR, Falowo OI, Bale LK, Zschunke MA, Roche PC, Conover CA. Functional insulin receptors on human epithelial ovarian carcinoma cells: implications for IGF-II mitogenic signaling. Endocrinology. 2002; 143:3259-67. [PubMed: 12193537]

28. Avnet S, Sciacca L, Salerno M, Gancitano G, Cassarino MF, Longhi A, et al. Insulin receptor isoform A and insulin-like growth factor II as additional treatment targets in human osteosarcoma. Cancer Res. 2009; 69:2443-52. [PubMed: 19258511]

29. Wahner Hendrickson AE, Haluska P, Schneider PA, Loegering DA, Peterson KL, Attar R, et al. Expression of insulin receptor isoform A and insulin-like growth factor-1 receptor in human acute myelogenous leukemia: effect of the dual-receptor inhibitor BMS-536924 in vitro. Cancer Res. 2009; 69:7635-43. [PubMed: 19789352]

30. Vella V, Pandini G, Sciacca L, Mineo R, Vigneri R, Pezzino V, et al. A novel autocrine loop involving IGF-II and the insulin receptor isoform-A stimulates growth of thyroid cancer. J Clin Endocrinol Metab. 2002; 87:245-54. [PubMed: 11788654]

31. Sciacca L, Mineo R, Pandini G, Murabito A, Vigneri R, Belfiore A. In IGFI receptor-deficient leiomyosarcoma cells autocrine IGF-II induces cell invasion and protection from apoptosis via the insulin receptor isoform A. Oncogene. 2002; 21:8240-50. [PubMed: 12447687]

32. Cox ME, Gleave ME, Zakikhani M, Bell RH, Piura E, Vickers E, et al. Insulin receptor expression by human prostate cancers. Prostate. 2009; 69:33-40. [PubMed: 18785179]

33. Gao J, Chesebrough JW, Cartlidge SA, Ricketts SA, Incognito L, Veldman-Jones M, et al. Dual IGF-I/II-neutralizing antibody MEDI-573 potently inhibits IGF signaling and tumor growth. Cancer Res. 2011; 71:1029-40. [PubMed: 21245093]

34. Therasse P, Arbuck SG, Eisenhauer EA, Wanders J, Kaplan RS, Rubinstein L, et al. New guidelines to evaluate the response to treatment in solid tumors. European Organization for Research and Treatment of Cancer, National Cancer Institute of the United States, National Cancer Institute of Canada. J Natl Cancer Inst. 2000; 92:205-16. [PubMed: 10655437]

35. Bao H, Burke PA, Huang J, Chen X, Brohawn PZ, Yao Y, et al. Circulating tumor cells: application as a biomarker for molecular characterization and predictor of survival in an all-comer solid tumor phase I clinical study. PLoS ONE. 2013; 8:e58557. [PubMed: 23990866]

36. Hayes DF, Cristofanilli M, Budd GT, Ellis MJ, Stopeck A, Miller MC, et al. Circulating tumor cells at each follow-up time point during therapy of metastatic breast cancer patients predict progression-free and overall survival. Clin Cancer Res. 2006; 12:4218-24. [PubMed: 16857794] 
37. de Bono JS, Scher HI, Montgomery RB, Parker C, Miller MC, Tissing H, et al. Circulating tumor cells predict survival benefit from treatment in metastatic castration-resistant prostate cancer. Clin Cancer Res. 2008; 14:6302-9. [PubMed: 18829513]

38. Cohen SJ, Punt CJ, Iannotti N, Saidman BH, Sabbath KD, Gabrail NY, et al. Relationship of circulating tumor cells to tumor response, progression-free survival, and overall survival in patients with metastatic colorectal cancer. J Clin Oncol. 2008; 26:3213-21. [PubMed: 18591556]

39. Cohen SJ, Punt CJ, Iannotti N, Saidman BH, Sabbath KD, Gabrail NY, et al. Prognostic significance of circulating tumor cells in patients with metastatic colorectal cancer. Ann Oncol. 2009; 20:1223-9. [PubMed: 19282466]

40. Gualberto A, Pollak M. Emerging role of insulin-like growth factor receptor inhibitors in oncology: early clinical trial results and future directions. Oncogene. 2009; 28:3009-21. [PubMed: 19581933]

41. Cohen BD, Baker DA, Soderstrom C, Tkalcevic G, Rossi AM, Miller PE, et al. Combination therapy enhances the inhibition of tumor growth with the fully human anti-type 1 insulin-like growth factor receptor monoclonal antibody CP-751,871. Clin Cancer Res. 2005; 11:2063-73. [PubMed: 15756033]

42. Broussas M, Dupont J, Gonzalez A, Blaecke A, Fournier M, Corvaia N, et al. Molecular mechanisms involved in activity of h7C10, a humanized monoclonal antibody, to IGF-1 receptor. Int J Cancer. 2009; 124:2281-93. [PubMed: 19165858]

43. Beltran PJ, Mitchell P, Chung YA, Cajulis E, Lu J, Belmontes B, et al. AMG 479, a fully human anti-insulin-like growth factor receptor type I monoclonal antibody, inhibits the growth and survival of pancreatic carcinoma cells. Mol Cancer Ther. 2009; 8:1095-105. [PubMed: 19366899]

44. Goodwin PJ, Ennis M, Pritchard KI, Trudeau ME, Koo J, Madarnas Y, et al. Fasting insulin and outcome in early-stage breast cancer: results of a prospective cohort study. J Clin Oncol. 2002; 20:42-51. [PubMed: 11773152]

45. Law JH, Habibi G, Hu K, Masoudi H, Wang MY, Stratford AL, et al. Phosphorylated insulin-like growth factor-i/insulin receptor is present in all breast cancer subtypes and is related to poor survival. Cancer Res. 2008; 68:10238-46. [PubMed: 19074892]

46. Ma J, Li H, Giovannucci E, Mucci L, Qiu W, Nguyen PL, et al. Pre-diagnostic body-mass index, plasma C-peptide concentration, and prostate cancer-specific mortality in men with prostate cancer: a long-term survival analysis. Lancet Oncol. 2008; 9:1039-47. [PubMed: 18835745]

47. Mathieu MC, Clark GM, Allred DC, Goldfine ID, Vigneri R. Insulin receptor expression and clinical outcome in node-negative breast cancer. Proc Assoc Am Physicians. 1997; 109:565-71. [PubMed: 9394418]

48. Wolpin BM, Meyerhardt JA, Chan AT, Ng K, Chan JA, Wu K, et al. Insulin, the insulin-like growth factor axis, and mortality in patients with nonmetastatic colorectal cancer. J Clin Oncol. 2009; 27:176-85. [PubMed: 19064975]

49. Zhang H, Pelzer AM, Kiang DT, Yee D. Down-regulation of type I insulin-like growth factor receptor increases sensitivity of breast cancer cells to insulin. Cancer Res. 2007; 67:391-7. [PubMed: 17210722]

50. Gradilone A, Petracca A, Nicolazzo C, Gianni W, Cortesi E, Naso G, et al. Prognostic significance of survivin-expressing circulating tumour cells in T1G3 bladder cancer. BJU Int. 2010; 106:710-5. [PubMed: 20128783]

51. Rink M, Chun FK, Dahlem R, Soave A, Minner S, Hansen J, et al. Prognostic role and HER2 expression of circulating tumor cells in peripheral blood of patients prior to radical cystectomy: a prospective study. Eur Urol. 2012; 61:810-7. [PubMed: 22277196]

52. Hoogwerf D, van DJ, Maartense E. The insulin-like growth factor-system in a patient with diffuse large B-cell non-Hodgkin's lymphoma and lactic acidosis. Ann Clin Biochem. 2013; 50:169-72. [PubMed: 23467067]

53. Koga T, Endo H, Miyamoto Y, Mukai M, Akira S, Inoue M. IGFBPs contribute to survival of pancreatic cancer cells under severely hypoxic conditions. Cancer Lett. 2008; 268:82-8. [PubMed: 18467023]

54. Koong AC, Denko NC, Hudson KM, Schindler C, Swiersz L, Koch C, et al. Candidate genes for the hypoxic tumor phenotype. Cancer Res. 2000; 60:883-7. [PubMed: 10706099] 
55. Robertson JF, Ferrero JM, Bourgeois H, Kennecke H, de Boer RH, Jacot W, et al. Ganitumab with either exemestane or fulvestrant for postmenopausal women with advanced, hormone-receptorpositive breast cancer: a randomised, controlled, double-blind, phase 2 trial. Lancet Oncol. 2013; 14:228-35. [PubMed: 23414585] 


\section{Translational Relevance}

This article reports the findings of a phase I, multi-center, open-label study evaluating the safety, tolerability, and antitumor activity of MEDI-573 in adult patients with advanced solid tumors refractory to standard therapy or for which no standard therapy exists.

Pharmaco-dynamic evaluations demonstrated that MEDI-573 was effective at sequestering insulin-like growth factor (IGF)-I and IGFII ligands at doses well below the dose that could be safely administered to patients. Importantly, MEDI-573 treatment demonstrated a favorable toxicity profile, with no metabolic derangements. This is important for the clinical-translational potential of MEDI-573, as lack of these metabolic adverse events may favor this IGF-targeting strategy over other approaches in patients with cancer. Of 39 patients evaluable for response, 13 had stable disease as best response. Based on these findings, MEDI-573 continues to be investigated in patients with cancer. 


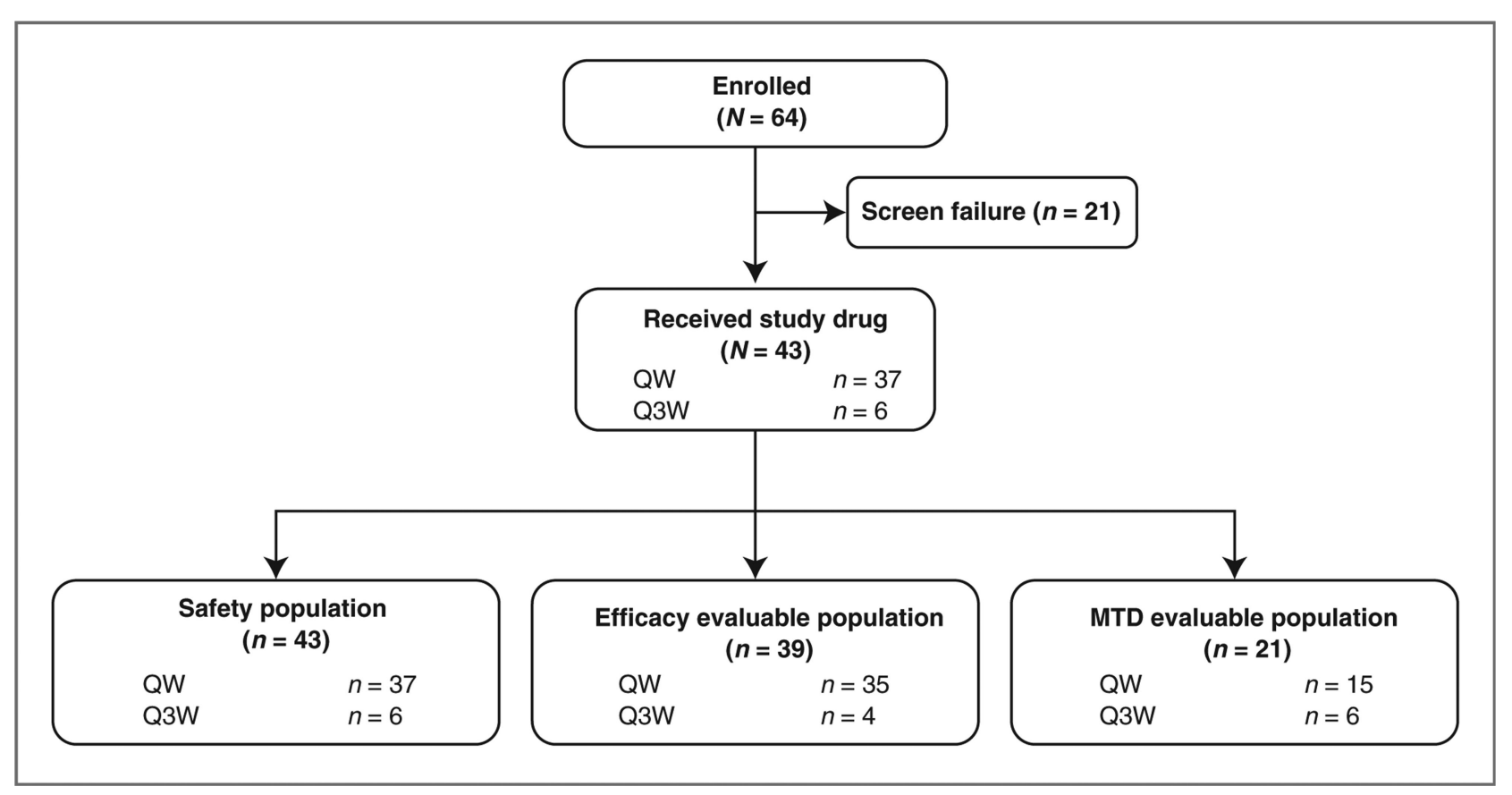

Figure 1.

Patient disposition. Abbreviations: QW, once weekly; Q3W, every 3 weeks. 


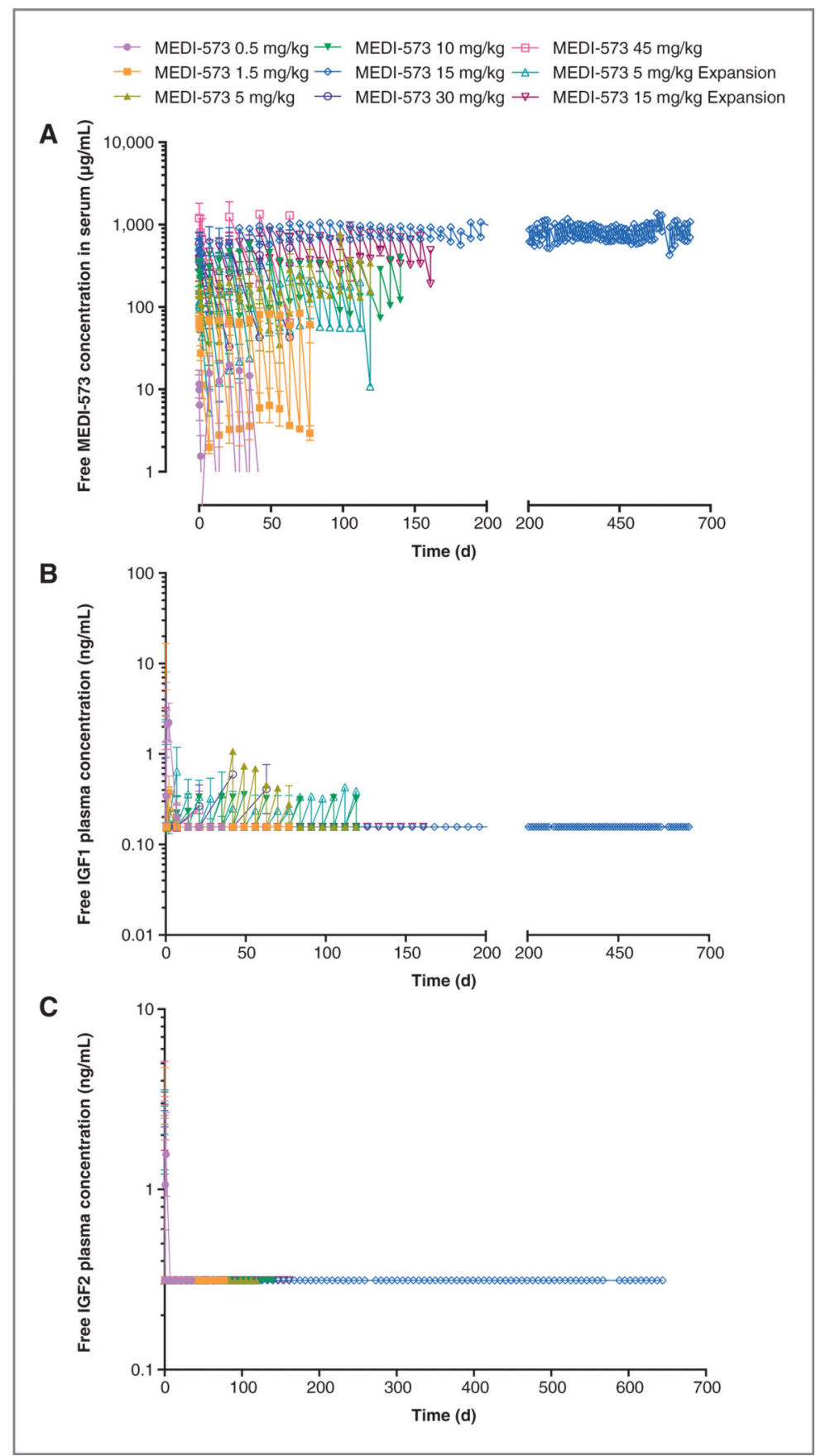

Figure 2.

PK and PD effects of MEDI-573. The graphs illustrate free MEDI-573 concentrations in serum (A), the suppression of IGF1 (B), and the suppression of IGF2 (C). Values indicate the mean $(\mathrm{SD})$ for each time point. 
Table 1

Baseline characteristics and disease status (safety population)

\begin{tabular}{|c|c|c|c|}
\hline Variable & 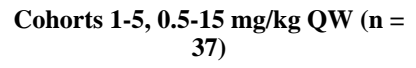 & $\begin{array}{c}\text { Cohorts 6-7, } 30-45 \mathrm{mg} / \mathrm{kg} \mathrm{Q3W}(n= \\
6)\end{array}$ & Total $(N=43)$ \\
\hline Age $(y)$, mean $(S D)$ & $62.6(11.5)$ & $62.0(12.7)$ & $62.6(11.6)$ \\
\hline Sex, $n$, male/female & $23 / 14$ & $2 / 4$ & $25 / 18$ \\
\hline \multicolumn{4}{|l|}{ Primary tumor type, $n$} \\
\hline Bladder & 20 & - & 20 \\
\hline Breast (adenocarcinoma) & 1 & - & 1 \\
\hline Cervical & - & 1 & 1 \\
\hline Colorectal & 1 & 1 & 2 \\
\hline Colon & 1 & - & 1 \\
\hline Esophageal & 1 & - & 1 \\
\hline Ewing's sarcoma & 1 & - & 1 \\
\hline Gastroesophageal & - & 1 & 1 \\
\hline Non-small cell lung & - & 1 & 1 \\
\hline Ovarian & - & 1 & 1 \\
\hline Prostate & 3 & - & 3 \\
\hline Other ${ }^{a}$ & 9 & 1 & 10 \\
\hline \multicolumn{4}{|c|}{ Baseline Karnofsky performance status } \\
\hline 70 & 6 & 3 & 9 \\
\hline 80 & 13 & 3 & 16 \\
\hline 90 & 13 & - & 13 \\
\hline 100 & 5 & - & 5 \\
\hline
\end{tabular}

Abbreviations: QW, once weekly; Q3W, every 3 weeks.

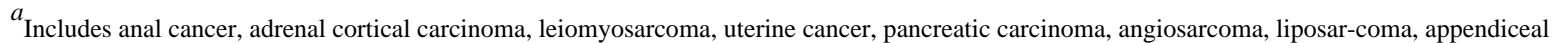
adenocarcinoma, and adenocarcinoma of unknown primary origin. 
Table 2

Treatment-related ${ }^{a}$ AEs by severity, according to CTCAE criteria

\begin{tabular}{|c|c|c|c|c|}
\hline \multirow[b]{2}{*}{$\mathrm{AE}, n(\%)$} & \multicolumn{2}{|c|}{ Cohorts 1-5, 0.5-15 mg/kg QW $(n=37)$} & \multicolumn{2}{|c|}{ Cohorts 6-7, 30-45 mg/kg Q3W $(n=6)$} \\
\hline & Grade 1/2 & Grade 3/4 & Grade 1/2 & Grade 3/4 \\
\hline Fatigue & $10(27)$ & 0 & $1(17)$ & $1(17)$ \\
\hline Decreased appetite & $9(24)$ & 0 & $1(17 \%)$ & 0 \\
\hline Nausea & $7(19)$ & 0 & $1(17)$ & 0 \\
\hline Diarrhea & $5(14)$ & 0 & $2(33)$ & 0 \\
\hline Anemia & $5(14)$ & 0 & 0 & 0 \\
\hline Vomiting & $3(8)$ & 0 & $1(17)$ & 0 \\
\hline Rash & $2(5)$ & 0 & $1(17)$ & 0 \\
\hline Pruritus & $1(3)$ & 0 & $2(33)$ & 0 \\
\hline Myalgia & $2(5)$ & 0 & 0 & 0 \\
\hline Leukopenia & $2(5)$ & 0 & 0 & 0 \\
\hline Thrombocytopenia & $2(5)$ & 0 & 0 & 0 \\
\hline Abdominal pain & $2(5)$ & 0 & 0 & 0 \\
\hline Stomatitis & 0 & 0 & $2(33)$ & 0 \\
\hline Increased alkaline phosphatase & $1(3)$ & 0 & $1(17)$ & 0 \\
\hline Constipation & $1(3)$ & 0 & 0 & 0 \\
\hline Dry mouth & $1(3)$ & 0 & 0 & 0 \\
\hline Peripheral edema & $1(3)$ & 0 & 0 & 0 \\
\hline Pyrexia & $1(3)$ & 0 & 0 & 0 \\
\hline Thirst & $1(3)$ & 0 & 0 & 0 \\
\hline Increased serum creatinine & $1(3)$ & 0 & 0 & 0 \\
\hline Increased growth hormone & $1(3)$ & 0 & 0 & 0 \\
\hline Increased insulin & $1(3)$ & 0 & 0 & 0 \\
\hline Decreased weight & $1(3)$ & 0 & 0 & 0 \\
\hline Hypocalcemia & $1(3)$ & 0 & 0 & 0 \\
\hline Hypomagnesemia & $1(3)$ & 0 & 0 & 0 \\
\hline Hypophosphatemia & $1(3)$ & 0 & 0 & 0 \\
\hline Back pain & $1(3)$ & 0 & 0 & 0 \\
\hline Somnolence & $1(3)$ & 0 & 0 & 0 \\
\hline Exertional dyspnea & $1(3)$ & 0 & 0 & 0 \\
\hline Pneumothorax & $1(3)$ & 0 & 0 & 0 \\
\hline Alopecia & $1(3)$ & 0 & 0 & 0 \\
\hline Early satiety & 0 & 0 & $1(17)$ & 0 \\
\hline Hypoglycemia & 0 & $1(3)$ & 0 & 0 \\
\hline Systolic hypertension & $1(3)$ & 0 & 0 & 0 \\
\hline
\end{tabular}

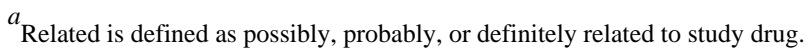


Table 3

Serious adverse events

\begin{tabular}{|c|c|c|}
\hline Dose, $\mathbf{m g} / \mathbf{k g}$ & $\begin{array}{l}\text { Number of patients/ } \\
\text { number of cohort }(n= \\
\text { 17) }\end{array}$ & SAEs $(n=34)$ \\
\hline 0.5 & $2 / 4$ & Increased blood creatinine, dehydration, fatigue, decreased GFR, neoplasm (disease progression) \\
\hline 1.5 & $1 / 3$ & Neoplasm (disease progression) \\
\hline 5.0 & $4 / 14$ & $\begin{array}{l}\text { Abdominal pain, diarrhea, device-related infection, urinary tract infection, cholangitis, urinary } \\
\text { tract obstruction }\end{array}$ \\
\hline 10.0 & $1 / 3$ & Neoplasm (disease progression) \\
\hline 15.0 & $6 / 13$ & $\begin{array}{l}\text { Hypoglycemia, decreased weight, }{ }^{a} \text { decreased appetite, }{ }^{a} \text { urosepsis, small intestine obstruction, } \\
\text { hypercalcemia, bacteremia, device-related infection, confusional state, hemoptysis, deep vein } \\
\text { thrombosis }\end{array}$ \\
\hline 30.0 & $0 / 3$ & - \\
\hline 45.0 & $3 / 3$ & $\begin{array}{l}\text { Abdominal distention, abdominal pain, vomiting, musculoskeletal chest pain, neoplasm (disease } \\
\text { progression), renal failure, respiratory failure }\end{array}$ \\
\hline
\end{tabular}

Abbreviation: GFR, glomerular filtration rate.

${ }^{a}$ Considered by investigators to be treatment related; occurred in the same patient. 
Table 4

\begin{tabular}{|c|c|c|c|c|c|}
\hline \multirow{11}{*}{ 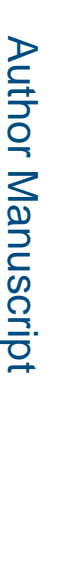 } & \multicolumn{5}{|c|}{ PK parameters after first dose ${ }^{a}$} \\
\hline & Dose (mg/kg) & Patients $(n)$ & $T_{\max }(d)$ & $\mathrm{C}_{\max }(\mu \mathrm{g} / \mathrm{mL})$ & $\operatorname{AUC}_{(0-7)}($ day $\cdot \mu \mathrm{g} / \mathrm{mL})$ \\
\hline & $0.5 \mathrm{QW}$ & 3 & $0.04(0.04-0.04)$ & $11.6(5.5)$ & $9.59(5.12)$ \\
\hline & $1.5 \mathrm{QW}$ & 3 & $0.04(0.04-0.04)$ & $71.8(12.5)$ & $90.8(18.6)$ \\
\hline & $5 \mathrm{QW}$ & 3 & $0.04(0.04-0.12)$ & $166(37.7)$ & $431(135)$ \\
\hline & $5 \mathrm{QW}$ expansion & 9 & $0.04(0.04-0.30)$ & $115(42.6)$ & 227 (99.8) \\
\hline & $10 \mathrm{QW}$ & 3 & $0.04(0.04-0.14)$ & $264(121)$ & $631(288)$ \\
\hline & $15 \mathrm{QW}$ & 3 & $0.28(0.12-0.30)$ & $560(251)$ & $1950(917)$ \\
\hline & $15 \mathrm{QW}$ expansion & 9 & $0.06(0.04-0.30)$ & $412(141)$ & $1280(392)$ \\
\hline & $30 \mathrm{Q} 3 \mathrm{~W}$ & 3 & $0.06(0.06-0.06)$ & $588(213)$ & $3510(1230)$ \\
\hline & $45 \mathrm{Q} 3 \mathrm{~W}$ & 3 & $0.06(0.06-0.06)$ & $1200(621)$ & $5790(3390)$ \\
\hline
\end{tabular}

Abbreviations: $\mathrm{AUC}_{0-7}$, area under the concentration-time curve from time zero to 7 days; $\mathrm{AUC}_{0-21}$, area under the concentration-time curve from time 0 to 21 days; $C_{\max }$, maximum observed serum concentration; $T_{\max }$, time to maximum observed concentration.

${ }^{a}$ Table reflects data collected as of December 20, 2011. Parameters are presented as mean (standard deviation) except $T_{\max }$, which is presented as median (minimum-maximum). 